\title{
Effects of edible coatings with various natural browning inhibitors on the qualitative characteristics of banana (Musa acuminata Cavendish Subgroup) during storage
}

\author{
Jiyoon Kim ${ }^{1}$, Ji-Young Choi ${ }^{1}$, Jungsoo Kim ${ }^{1}$, Kwang-Deog Moon ${ }^{1,2 *}$ \\ ${ }^{1}$ School of Food Science and Technology, Kyungpook National University, Daegu 41566, Korea \\ ${ }^{2}$ Food and Bio-industry Research Instiute, Kyungpook National University, Daegu 41566, Korea

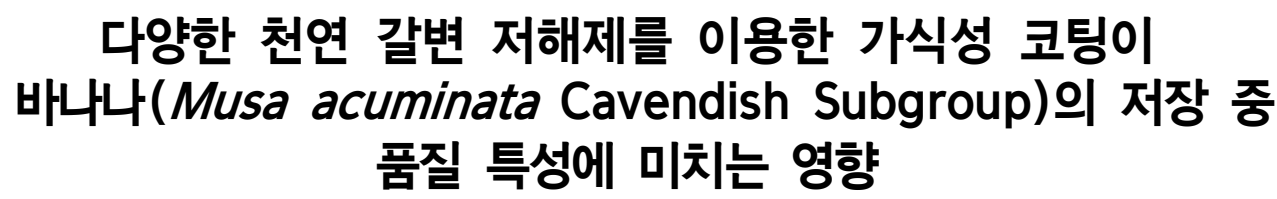 \\ 김지윤 ${ }^{1} \cdot$ 최지영 ${ }^{1} \cdot$ 김정수 $^{1} \cdot$ 문광덕 $^{1,2 *}$ \\ 1경북대학교 식품공학부, ${ }^{2}$ 경북대학교 식품생물산업연구소
}

\begin{abstract}
Bananas (Musa acuminata Cavendish Subgroup) have a short shelf-life due to surface browning. This study aimed to select the best edible coating agent including a natural browning inhibitor (green tea, Rhus chinensis, rice bran and Morus alba root extracts) that can extend the shelf-life of bananas. Bananas were coated with $1.5 \%$ carboxymethyl cellulose and 2.0\% Tween $80(\mathrm{CM}), \mathrm{CM}$ and $1.5 \%$ green tea extract, $\mathrm{CM}$ and $1.5 \%$ Rhus chinensis extract, $\mathrm{CM}$ and rice bran extract, and $\mathrm{CM}$ and $1.5 \%$ Morus alba extract (CM-M). An uncoated sample was used as the control. The weight loss, firmness, polyphenol oxidase (PPO) activity, browning index (BI), total chlorophyll content, and color of the coated bananas during storage were evaluated. Treatment with CM-M exhibited lesser changes in the weight and firmness of bananas during storage, compared with the other treatments. Moreover, CM-M delayed the enzymatic browning of bananas during storage, maintained the PPO activity, and showed the lowest BI, compared with other treatments. The changes in the total chlorophyll content and color ( $\triangle \mathrm{E}$ value) were lower in the CM-M coated samples than in the control samples. The CM-M coated samples showed decreases in the total chlorophyll content and $\Delta \mathrm{E}$ value compared with that noted in bananas with the other coatings. Therefore, our findings indicated Morus alba root extract supplementation to be the most suitable edible coating agent, which maintains the quality and appearance of bananas during storage.
\end{abstract}

Key words : edible coating, banana (Musa acuminata Cavendish Subgroup), browning inhibitor, carboxyl methyl cellulose, ripening

서 론

바나나(Musa acuminata Cavendish Subgroup)는 파초과
에 속하는 식물로 인도, 중국, 필리핀 등에서 주로 생산되고 있으며 칼륨, 비타민 $\mathrm{C}$ 및 $\mathrm{B}_{6}$, 섬유질, 트립토판 등의 아미노 산이 풍부하다(Sheehy과 Sharma, 2011). 바나나는 녹색 단계

*Corresponding author. E-mail : kdmoon@knu.ac.kr, Phone : +82-53-950-5773, Fax :+82-53-950-6772

Received 10 September 2020; Revised 07 November 2020; Accepted 04 December 2020.

Copyright (c) The Korean Society of Food Preservation.

This is an Open Access article distributed under the terms of the Creative Commons Attribution Non-Commercial License (http://creativecommons.org/licenses/by-nc/4.0) which permits unrestricted non-commercial use, distribution, and reproduction in any medium, provided the original work is properly cited. 
에서 수확되며 숙성 중 엽록소의 파괴로 인해 과피가 황색으 로 변화한다(Dadzie와 Orchard, 1997). 바나나의 숙성이 진 행될수록 황색 바탕에 불균일한 갈색 반점이 나타나게 되고, 반점이 많아지면 결국 갈색으로 보이게 되는 특성을 가지고 있다(Choehom 등, 2004). 이러한 바나나의 갈변은 유통 과정 에서 매우 빠르게 진행되기 때문에 치명적인 품질 저하로 이 어지며, 수확 후 충격 및 압박을 받을 경우 표피 갈변과 과육 의 연화로 인해 상품가치가 현저하게 떨어지는 문제는 바나 나 산업에 있어서 많은 문제가 되고 있다(Huang 등, 2013; Kim과 Youn, 2013). 따라서 바나나 껍질 색상은 품질을 결정 하는데 있어 가장 중요한 요소로 판단될 수 있으며, 이를 조절 할 수 있는 기술의 개발이 필요하다(Mendoza와 Aguilera, 2004). 과일의 품질 유지나 갈변 방지를 위해 환원제 및 킬레 이트제 등의 화학 물질을 직접 처리하거나(Son 등, 2016), 효 소 활성 조절을 이용하는 열처리(Sim 등, 2016), 물질의 투과 성을 제어하는 가식성 코팅처리(Hur, 2015) 및 저장 환경 기 체 조성을 변경하는 포장처리(Kim 등, 2017) 등의 방법이 다 양하게 이용되고 있다.

가식성 코팅은 '가스, 수증기 및 용재의 투과를 선택적으 로 차단하는 동시에 물리적 보호 효과를 부여하기 위해 포장, 담금, 도포, 분무 등의 방법으로 가식성 물질을 식품 표면에 얇은 층막으로 입힌 것'으로 정의된다(Baldwin 등, 1995). 가 식성 코팅은 활성 포장의 한 가지 형태로 포장 내, 외부 환경 과 능동적인 상호 작용을 통하여 식품 포장 성능을 향상시키 는데 도움을 준다. 또한 수분과 기체 교환에 대한 부분적인 barrier로 작용될 수 있고, 식품첨가물(갈변억제제, 항균제)들 을 함께 적용할 수 있는 장점이 있다(Debeaufort 등, 1998). 가식성 코팅제로 이용되는 소재는 다당류, 단백질, 지방 등이 있으며, 이중 carboxymethyl cellulose(CMC)는 다당류 기반 의 소재로서 가용성이며 긴 사슬 구조의 분자 구조를 가지고 있고, 수용성 및 음 이온성이라는 특징이 있다(Chiumarelli 와 Hubinger, 2012; Fernandez-Pan 등, 2014; Hassan 등, 2018). 또한 $\mathrm{CMC}$ 를 가식성 코팅으로 적용할 때 반투과성 장 벽으로서의 작용을 하여 수분 및 용질 가스 교환을 억제함으 로써 유통기한을 연장할 수 있다(Saba와 Sogvar, 2016). 화학 물질 대용으로 과일의 갈변 억제에 유효한 것으로 알려진 녹 차(Camellia sinensis), 붉나무(Rhus chinensis), 쌀겨(Oryza sativa Bran), 뽕나무의 뿌리껍질인 상백피(Morus alba)와 같 은 천연물 유래 추출물은 높은 항산화력으로 인해 과일의 산 화를 방지하고 갈변을 지연시킬 수 있다는 연구 결과를 확인 할 수 있다(Chang 등, 2012; Jee 2009; Noh 등, 2017; Park 등, 2014). 그러나 가식성 코팅에 다양한 천연 갈변 저해제를 첨가하여 코팅제별 갈변 저해 효과를 비교한 연구는 거의 찾 아볼 수 없다.
따라서 본 연구에서는 바나나의 갈변을 저해할 수 있는 기 술을 개발하기 위한 기초 자료를 얻기 위해 범용되고 있는 다양한 갈변 저해제를 달리하여 제조한 가식성 코팅을 적용 하였다. 그 후 저장기간 동안 바나나의 중량감소율, 경도, polyphenol oxidase(PPO) 활성, browning index(BI), 총엽록 소 함량, 색차 및 색도에 미치는 영향을 조사하여 품질 특성 유지에 가장 적합한 가식성 코팅의 갈변저해 효과를 확인하 였다.

\section{재료 및 방법}

\section{실험재료}

바나나(Musa acuminata Cavendish Subgroup)는 필리핀 부키드논 주에서 재배되었으며, 2020년도 1월 대구광역시 농 산물 시장에서 구입하였다. 육안으로 판별 시 외관 색택이 균 일하고 상처가 없는 $120.0 \pm 20.0 \mathrm{~g}$ 의 바나나를 선별한 후 200 $\mathrm{ppm}$ 농도의 $\mathrm{NaClO}$ 용액에 1 분간 침지한 후 증류수로 세척 하고, 겉에 묻은 물기를 제거하여 실험을 진행하였다. 천연 갈변 저해제는 녹차, 붉나무, 쌀겨, 상백피 분말 각 $100 \mathrm{~g}$ 에 10 배의 증류수를 첨가하여 $40^{\circ} \mathrm{C}$ 에서 12 시간 진탕 추출한 뒤 고형분 함량이 $0.5^{\circ} \mathrm{Brix}$ 가 되도록 증류수로 희석한 추출물 을 (주)다인솝(Cheongju, Korea)으로부터 제공 받아 사용하였 다. 열수 추출한 천연 갈변저해제들을 가식성 코팅제의 제조 에 이용하였다.

\section{가식성 코팅제의 제조}

코팅제는 증류수에 carboxyl methyl cellulose sodium salt(CMC)(Tokyo Chemicals Industry Co., Ltd., Tokyo, Japan) $1.5 \%(\mathrm{w} / \mathrm{v})$, Tween 80(Daejung Chemicals \& Metals Co., Ltd., Siheung, Korea) $2.0 \%(\mathrm{w} / \mathrm{v})$ 와 다양한 천연 갈변 저해제(녹차, 붉나무, 쌀겨, 상백피)를 $1.5 \%(\mathrm{w} / \mathrm{v})$ 첨가하여 $40( \pm 5)^{\circ} \mathrm{C}$ 에서 12 시간 동안 $120 \mathrm{rpm}$ 의 속도로 혼합하여 제조 하였다. 실험에 사용된 샘플은 무처리구 $(\mathrm{CON})$ 와 코팅제는 갈변 저해제를 첨가하지 않은 코팅제 $1.5 \% \mathrm{CMC}$ 와 $2.0 \%$ Tween80)(CM), CM과 $1.5 \%$ 갈변저해제를 첨가한 녹차 추 출물 코팅제 $(\mathrm{CM}-\mathrm{G})$, 붉나무 추출물 코팅제(CM-R), 쌀겨 추출 물 코팅제(CM-B), 상백피 추출물 코팅제 $(\mathrm{CM}-\mathrm{M})$ 를 제조하 여 바나나에 처리한 후 품질특성 및 성분함량을 측정하였다.

\section{가식성 코팅제의 처리 및 저장}

가식성 코팅제의 처리는 hand brushing 방법을 이용하여 진행하였다. 넓은 평붓으로 가로로 눕힌 바나나의 단면에 코 팅제를 1회 도포하고 dryer(BL950903, Gumbok Stoke Co., Ltd., Seoul, Korea)를 이용해 $20^{\circ} \mathrm{C}$ 에서 15 분간 건조하는 방 
식으로 한 면에 2 회, 한 개체당 총 4 번의 코팅을 진행하였다. 시료의 저장은 $13^{\circ} \mathrm{C}$ 항온기(JSBI-300C, JS Research Inc., Gongju, Korea)에서 12일간 보관하며 3일 간격으로 분석하 였으며, 저장 0 일차의 경우 코팅제의 처리 후 완전히 건조하 여 부착했다고 판단되는 2 시간 후 분석을 진행하였다(Eum 등, 2009). 그리고 CM-M을 제외한 다른 코팅 처리구에서 저 장 12 일차 이후부터 시료의 외관 갈변이 무처리구 $(\mathrm{CON})$ 와 유사하게 진행되었기 때문에 실험에 사용하기 부적합하다고 판단되어 실험에서 제외하였다.

\section{중량감소율 측정}

바나나의 중량 감소율은 저장기간 동안 바나나의 전체 질 량의 감소 정도를 백분율로 나타낸 값이며, 6 회 반복 측정 후 다음 식에 의해 산출하였다.

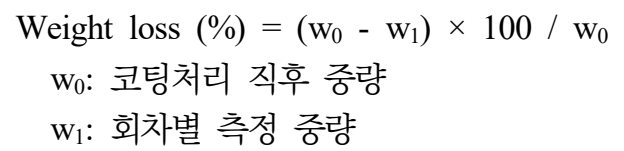

\section{경도 측정}

바나나의 경도 측정은 껍질을 제거하지 않은 바나나 표면 의 가운데와 양쪽 $1 / 3$ 지점의 경도(firmness)를 측정하였다. 경도 측정은 rheometer(Compac-100II, Sunscientific Co., Tokyo, Japan)를 이용하였으며, 각 바나나별로 3 회, 총 18회 측정 후 평균값으로 나타내었다. 물성 측정 시 측정조건은 sample type: cylinder, Table speed: $180 \mathrm{~mm} / \mathrm{min}$, distance: $6.80 \mathrm{~nm}(20 \%)$ 조건에서 $3 \mathrm{~mm}$ circle type adaptor를 사용하 여 측정하였다.

\section{$\mathrm{PPO}$ 활성 측정}

PPO 활성은 Yang(2009)의 방법을 변형하여 측정하였다. 바나나 껍질 $5 \mathrm{~g}$ 에 polyvinylpolypyrrolidone(PVPP, Sigma Chemical Co., St. Louis, MO, USA) 2.5 g과 $0.2 \mathrm{M}$ sodium phosphate buffer(pH 7.0) $45 \mathrm{~mL}$ 를 가하여 30초간 균질화했다. 균질액을 원심분리기(1580MGR, Gyrozen, Deajeon, Korea)로 $10,000 \times g, 4^{\circ} \mathrm{C}$ 에서 5 분간 원심분리한 후 얻은 상등액을 조 효소액으로 사용하였다. 조효소액 $0.6 \mathrm{~mL}$ 와 $20 \mathrm{mM}$ catechol (1,2-dihydroxybenzene, Sigma Chemical Co.)을 포함한 0.05 $\mathrm{M}$ sodium phosphate buffer(pH 7.0) $2.4 \mathrm{~mL}$ 를 반응시킨 후 UV-visible spectrophotometer(Evolution 201, ThermoFisher Scicentific, Waltham, MA, USA)를 이용하여 $420 \mathrm{~nm}$ 에서 흡광도를 측정하였다. PPO 활성은 1 분당 0.001 의 흡광도 변 화량을 1 unit로 하여 unit $/ \mathrm{g} / \mathrm{min}$ 으로 나타내었다.

\section{Browning index(BI) 측정}

BI는 Supapvanich 등(2011)의 방법을 변형하여 분석하였 다. 바나나 껍질 $2 \mathrm{~g}$ 에 $65 \%$ ethanol 용액(Duksan Pure Chemicals Co., Ltd., Ansan, Korea) $40 \mathrm{~mL}$ 를 넣고 $35^{\circ} \mathrm{C}$ 에서 40 $\mathrm{kHz}$ 의 초음파를 가하여 1시간 동안 추출 후 여과(Whatman No.2 filter paper)하였다. 여과액은 UV-visible spectrophotometer(Evolution 201, ThermoFisher Scicentific)를 이용하여 $420 \mathrm{~nm}$ 에서 흡광도를 측정하여 갈변 지수는 $\mathrm{ABS}(420 \mathrm{~nm})$ 값 으로 나타내었다.

\section{총 엽록소 함량 측정}

총엽록소 함량 측정은 Jatoi 등(2017)의 방법을 변형하여 측정하였다. 바나나 껍질 $3 \mathrm{~g}$ 에 $90 \%$ acetone(Duksan Pure Chemicals Co., Ltd.)용액 $27 \mathrm{~mL}$ 를 가한 뒤 Shaking incubator (JSSI-300C, JS Research Inc.)를 이용하여 $20^{\circ} \mathrm{C}$ 에서 180 $\mathrm{rpm}$ 의 속도로 30 분 동안 추출한 후 암실에 24시간 방치하였 다. 추출물을 여과(Whatman No.4 filter paper)하여 여과액을 $0.20 \mu \mathrm{m}$ membrane filter로 한 번 더 여과한 후 $663 \mathrm{~nm}$ 및 $645 \mathrm{~nm}$ 에서 UV-visible spectrophotometer(Evolution 201, ThermoFisher Scicentific)를 이용하여 흡광도를 측정하였다. 총 엽록소 함량은 3 회 반복 측정 후 다음 식에 의해 산출하 였다.

Chlorophyll a $=12.7 \times \mathrm{A}_{663} \mathrm{~nm}-2.995 \times \mathrm{A}_{645} \mathrm{~nm}$

Chlorophyll $\mathrm{b}=22.95 \times \mathrm{A}_{645} \mathrm{~nm}-4.67 \times \mathrm{A}_{663} \mathrm{~nm}$

Total chlorophyll $(\mathrm{g} / \mathrm{mL})=$ chlorophyll $\mathrm{a}+$ chlorophyll $\mathrm{b}$

\section{색도 및 색차 측정}

바나나의 색도 측정은 껍질을 제거하지 않은 바나나 표면 의 가운데와 양쪽 $1 / 3$ 지점을 측정하였다. 백색판 $\left(\mathrm{L}^{*}=97.79\right.$, $\mathrm{a}^{*}=-0.38, \mathrm{~b}^{*}=2.05$ )으로 보정된 colorimeter(CR-400, Konica Minolta Co., Osaka, Japan)를 이용해 CIELAB 값을 측정하 였으며, 명도( $\mathrm{L}^{*}=$ lightness $)$, 적색도( $\left.\mathrm{a}^{*}=\mathrm{redness}\right)$, 황색도( $\mathrm{b}^{*}=$ yellowness)로 나타냈다. Total color $\operatorname{different}(\Delta \mathrm{E})$ 는 다음 식 에 의해 산출하였다.

$$
\begin{gathered}
\Delta \mathrm{E}=\left[\left(\mathrm{L}^{*}-\mathrm{L}_{0}{ }^{*}\right)^{2}+\left(\mathrm{a}^{*}-\mathrm{a}_{0}{ }^{*}\right)^{2}+\left(\mathrm{b}^{*}-\mathrm{b}_{0}{ }^{* 0}\right)^{2}\right]^{1 / 2} \\
\mathrm{~L}_{0}{ }^{*}: \text { Initial lightness value of the source } \\
\mathrm{a}_{0}{ }^{*}: \text { Initial redness value of the source } \\
\mathrm{b}_{0}{ }^{*}: \text { Initial yellowness value of the source }
\end{gathered}
$$

\section{통계분석}

실험은 3회 이상 반복 측정하여 평균과 표준편차로 표시하 였다. 또한 유의성 검정을 위해 SPSS software package 
(Version 25, SPSS Inc., Chicago, IL, USA) 프로그램을 사용 하여 분산분석(ANOVA)을 실시하여 $p<0.05$ 수준에서 처리 샘플 간, 저장 일차 간 Duncan의 다중범위검정을 실시하였 다. 그리고 저장 12 일차의 경우 샘플간 t-test를 실시하였다.

\section{결과 및 고찰}

\section{중량감소율}

코팅 처리한 바나나의 저장 중 중량감소율의 변화는 Fig. 1 과 같다. 중량감소율은 저장 기간이 증가함에 따라 전반적으 로 증가하는 경향을 보였다. 특히 $\mathrm{CON}$ 의 경우, 저장 6 일차부 터 급격하게 증가하여 저장 12 일 후에는 $42.45 \pm 2.45 \%$ 로 가장 큰 증가율을 보였으며, $\mathrm{CM}-\mathrm{M}$ 의 경우 $5.98 \pm 0.79-17.22 \pm 3.80 \%$ 로 꾸준하게 낮은 결과를 유지했다. Adeyemi와 Oladiji(2009) 에 따르면 바나나의 수분 함량은 약 $70-80 \%$ 로 구성되어 있 으며, 과일의 중량 감소는 과일 조직 내부의 수분이 외부로 빠져나가는 증산현상 또는 호흡 과정에서 발생하게 된다(Cha 등, 2008). Kanatt와 Makwana(2020)에 따르면 코팅제의 재료 중 $\mathrm{CMC}$ 는 친수성이나 수분의 이동에 대한 제한적 저항성을 가지고 있고, 바나나의 외부에 코팅제 처리를 통해 증산현상 및 호흡을 제어할 수 있었다. $\mathrm{CMC}$ 와 모링가 추출물 기반의 코팅 처리를 함으로써 인해 아보카도의 중량 감소를 방지한다 는 Saowakon 등(2017)의 연구에서도 유사한 결과를 확인할 수 있었다. 이와 유사하게 CM-M 처리를 통해 바나나의 저장 중 중량 감소 현상을 감소시켰을 것으로 판단된다.

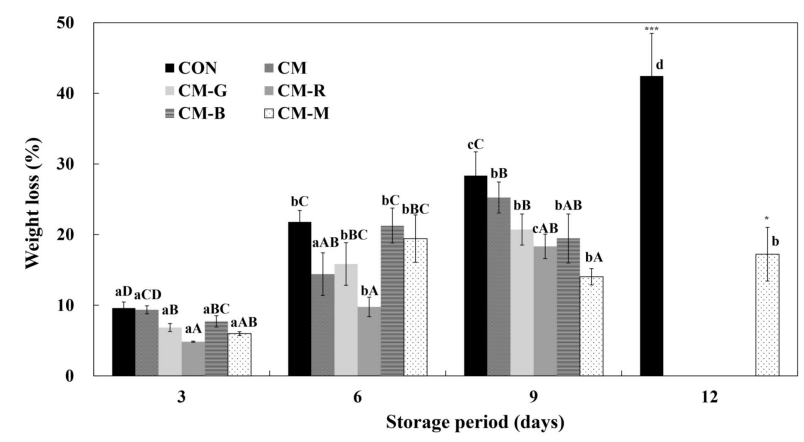

Fig. 1. Weight loss of edible coating bananas during storage.

$\mathrm{CON}$, no treatment; CM, applied only $1.5 \%$ carboxymethyl cellulose and $2.0 \%$ Tween 80 ; CM-G, applied CM $+1.5 \%$ green tea extract; CM-R, applied $\mathrm{CM}+1.5 \%$ Rhus chinensis extract; $\mathrm{CM}-\mathrm{B}$, applied $\mathrm{CM}+$ rice bran extract; CM-M, applied CM $+1.5 \%$ Morus alba extract. Different capital letters mean in a between groups of storage period by different superscripts are significantly different $(p<0.05)$ by Duncan's multiple range test.

Different small letters mean in a between groups of samples by different superscripts are significantly different $(\mathrm{p}<0.05)$ by Duncan's multiple range test.

${ }^{* * *}$ Means in a between groups of sample on 12 days are significantly different $(\mathrm{p}<0.001)$ by t-test.
경도

바나나는 저장 중 숙성과정에서 세포막의 손상으로 인해 무름 현상이 발생하게 되고, 이는 바나나의 품질을 평가하는 데 있어 중요한 요소 중 하나이다(Chauhan 등, 2006). 가식성 코팅 처리한 바나나의 저장 중 경도(firmness)의 변화는 Fig. 1 과 같다. 경도는 저장 기간이 경과함에 따라 감소하는 경향 이 있었으며, 저장 일차 간 유의적 차이를 확인할 수 있었다.

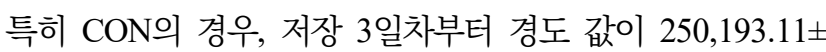
$3,222.63 \mathrm{~g} / \mathrm{cm}^{2}$ 에서 $114,470.35 \pm 24,319.85 \mathrm{~g} / \mathrm{cm}^{2}$ 로 2배 이상 감소하는 경향을 보이는 반면, $\mathrm{CM}-\mathrm{M}$ 의 경우 저장 9 일차까 지 값을 $107,345.74 \pm 11,560.35 \mathrm{~g} / \mathrm{cm}^{2}$ 로 유지하는 것을 확인 할 수 있다. 과일의 물성은 호흡, 세포의 팽압력, 세포 열화 및 세포벽 파괴에 의한 수분 손실 등 여러 가지 요인에 의해 변화할 수 있다(Martinez-Ferrer 등, 2002). 다당류인 CMC는 세포벽에 있는 펙틴 성분과 상호 작용하여 세포벽의 구조를 단단하게 하고, 기계적 강도를 높이게 된다(Lara-Espinoza 등, 2018). 또한 Kim 등(2010)에 따르면 상백피는 매우 높은 항 산화력을 가지고 있는데, 가식성 코팅 처리를 통해 호흡 등의 산화 작용을 지연시켰고, 이를 통해 세포 열화 및 세포벽 파 괴를 억제시켰을 것으로 여겨진다. Alginate와 gellan 기반의 다당류를 코팅처리 함으로써 fresh-cut 사과의 경도를 유지시 킨다는 Rojas-Grau 등(2008)의 연구에서도 유사한 결과를 확 인할 수 있었다. 따라서 $\mathrm{CMC}$ 와 상백피 추출물 기반의 CM-M 처리를 통해 바나나의 경도를 가장 오래 유지할 수 있었던 것으로 보인다.

\section{$\mathrm{PPO}$ 활성}

$\mathrm{PPO}$ 는 효소적 갈변과 관련된 대표적인 효소로 알려져 있 으며, 효소적 갈변 측정의 지표로 활용될 수 있다(Jang과 Moon, 2011). 가식성 코팅 처리한 바나나의 저장 중 외관의 변화는 Fig. 2과 같으며, $\mathrm{PPO}$ 활성의 변화는 Fig. 3 과 같다. $\mathrm{PPO}$ 활성 값은 저장 0 일차 $19.11 \pm 0.42-22.17 \pm 1.20 \mathrm{unit} / \mathrm{g} / \mathrm{min}$ 에서 저장 12 일차에는 $31.50 \pm 0.21-62.17 \pm 0.27 \mathrm{unit} / \mathrm{g} / \mathrm{min}$ 으로 측정되었다. 실험 결과 중 저장 6 일차 대부분의 결과 값이 유 의하게 낮게 나타나는데, 이 기간 동안 효소 활성의 수준은 낮았으나, 저장 9 일차부터 과피 외관에 갈변이 급격하게 진 행되면서 효소 활성의 값이 급격히 증가하였다. 이것은 바나 나의 외관 변화(Fig. 2)와 색차(Table 1)값과 유사한 결과임 을 확인할 수 있으며, 이 결과를 통해 바나나 과피의 갈변이 $\mathrm{CM}-\mathrm{M}$ 에 비해 $\mathrm{CON}$ 에서 특히 빠르게 발생했음을 나타낸다. 이는 포장 방법을 달리하여 저장한 바나나의 과피 갈변을 분 석한 Jeong 등(2016)의 연구 결과와 유사한 결과를 확인할 수 있다. 또한 갈변 저해에 효과가 있는 가식성 코팅을 식품 에 적용할 경우 o-quinone 화합물을 diphenol로 환원시켜 
$\mathrm{CON}$

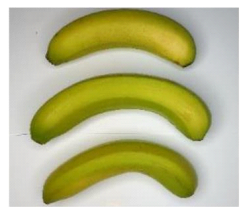

3 days

6 days
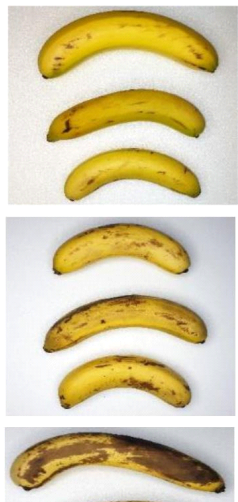

9 days

12 days
$\mathrm{CM}$
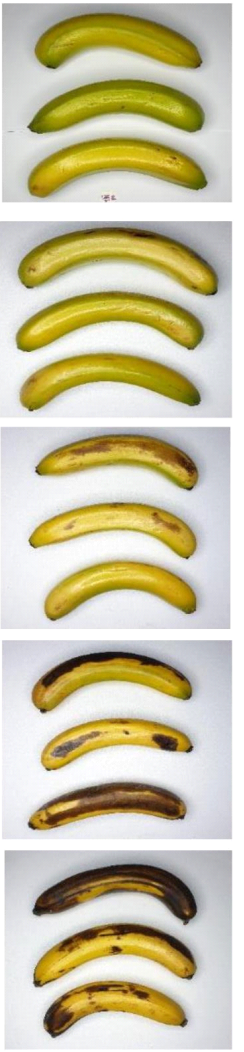

CM-G
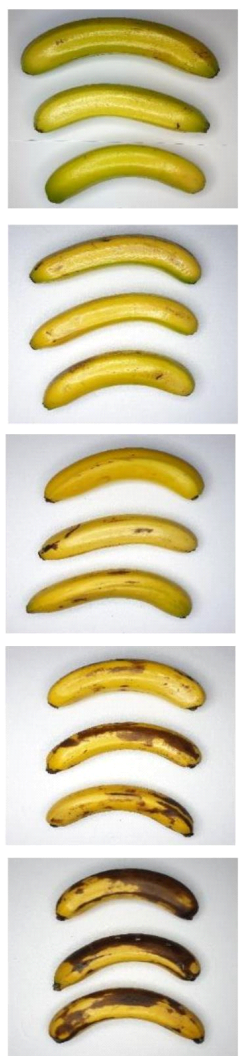

CM-R
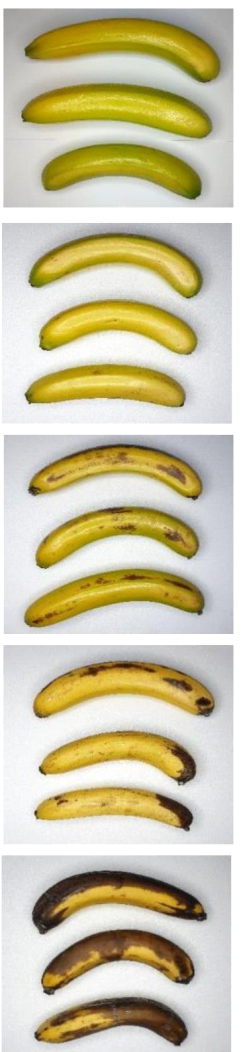

CM-B
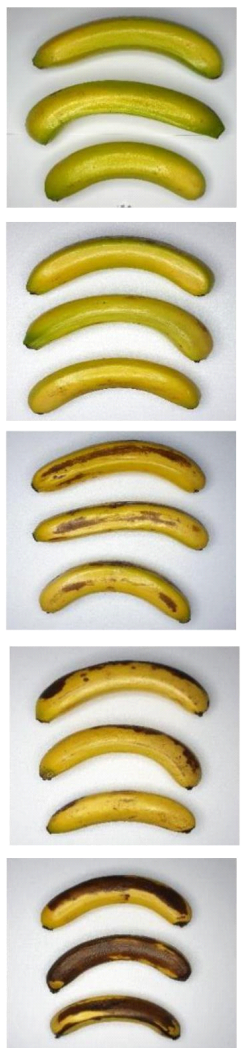

CM-M

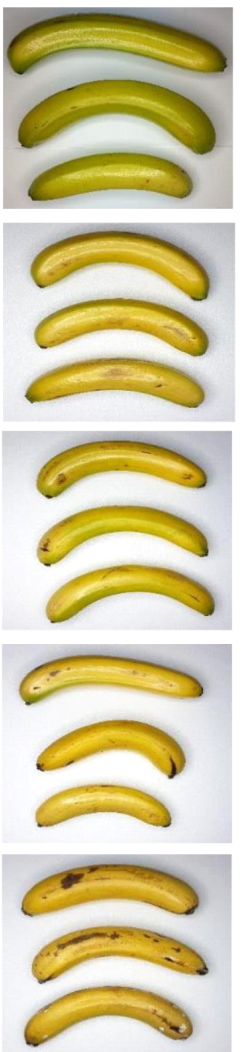

Fig. 2. Appearance of edible coating banana during storage.

0-12 days means the storage period of edible coating bananas; CON, no treatment; $\mathrm{CM}$, applied only $1.5 \%$ carboxymethyl cellulose and $2.0 \%$ Tween80; CM-G, applied CM + 1.5\% green tea extract; CM-R, applied CM + 1.5\% Rhus chinensis extract; CM-B, applied CM + rice bran extract; CM-M, applied CM + 1.5\% Morus alba extract.

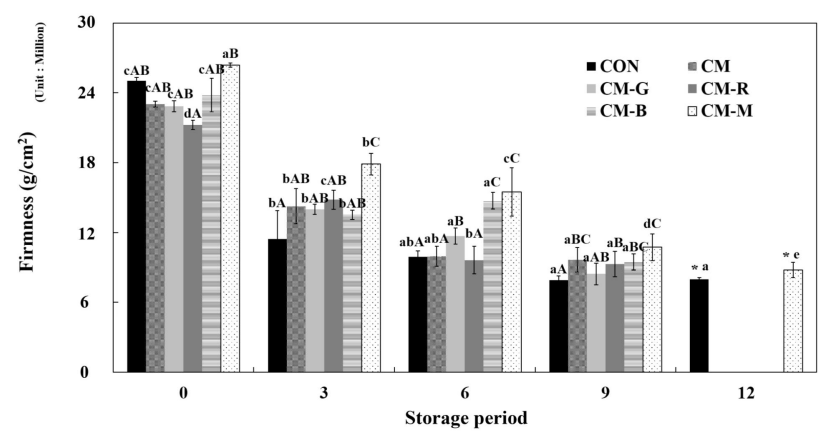

Fig. 3. Firmness of edible coating bananas during storage.

$\mathrm{CON}$, no treatment; $\mathrm{CM}$, applied only $1.5 \%$ carboxymethyl cellulose and $2.0 \%$ Tween $80 ; \mathrm{CM}-\mathrm{G}$, applied $\mathrm{CM}+1.5 \%$ green tea extract; CM-R, applied $\mathrm{CM}+1.5 \%$ Rhus chinensis extract; $\mathrm{CM}-\mathrm{B}$, applied $\mathrm{CM}+$ rice bran extract; CM-M, applied CM $+1.5 \%$ Morus alba extract.

Different capital letters mean in a between groups of storage period by different superscripts are significantly different $(p<0.05)$ by Duncan's multiple range test.

Different small letters mean in a between groups of samples by different superscripts are significantly different $(p<0.05)$ by Duncan's multiple range test.

*Means in a between groups of sample on 12 days are significantly different $(\mathrm{p}<0.001)$ by $\mathrm{t}$-test.
$\mathrm{PPO}$ 활성을 간접적으로 억제하는 환원제로써 작용을 하게 되었다는 Tinello와 Lante(2018)의 연구 결과에 따라 CM-M 처리를 통해 바나나의 갈변을 저해했을 것으로 보인다. $\mathrm{CMC}$ 기반의 코팅 처리를 통해 자두의 $\mathrm{PPO}$ 활성을 늦춘다는 Ghasemnezhad 등(2012)의 연구 결과와 유사한 결과를 보였 으며, CM-M 처리를 통해 PPO 활성을 늦출 수 있었다.

\section{Browning index(BI)}

바나나의 저장 중 갈변에 영향을 줄 수 있는 요인은 갈변 및 노화과정과 관련된 효소 활성 등이 있으며, 특히 PPO 및 peroxidase(POD) 효소의 활성을 통해 갈변이 촉진된다(Kader, 2002). 가식성 코팅 처리한 바나나의 저장 중 $\mathrm{BI}$ 의 결과는 Fig. 4와 같으며, 과피의 갈색소를 열수 추출하여 측정한 지수 를 말한다. 저장 기간이 경과함에 따라 바나나 표면의 BI 값 이 전반적으로 증가하는 경향을 보였다. 저장 9 일차에서 $\mathrm{CM}-\mathrm{M}$ 및 $\mathrm{CM}-\mathrm{R}$ 처리구의 $\mathrm{BI}$ 값은 $0.474 \pm 0.017$ 및 $0.410 \pm$ 0.017 로 $\mathrm{CON}$ 처리구에 비해 유의적으로 낮았으며, 저장 기 
Table 1. Changes in color value (CIE L $\left.\mathbf{L}^{*} \mathrm{~b}^{*}\right)$ and color different $(\Delta \mathrm{E})$ of edible coated bananas during storage

\begin{tabular}{|c|c|c|c|c|c|c|c|}
\hline \multirow{2}{*}{$\begin{array}{l}\text { Color } \\
\text { value }^{1)}\end{array}$} & \multirow{2}{*}{$\begin{array}{l}\text { Storage } \\
\text { periods }\end{array}$} & \multicolumn{6}{|c|}{ Samples ${ }^{2)}$} \\
\hline & & $\mathrm{CON}$ & $\mathrm{CM}$ & CM-G & CM-R & CM-B & CM-M \\
\hline \multirow{5}{*}{$\mathrm{L}^{*}$} & 0 & $64.32 \pm 4.54^{3) \mathrm{d} 4) \mathrm{A} 5)}$ & $65.61 \pm 4.13^{\mathrm{cA}}$ & $70.13 \pm 2.02^{\mathrm{aB}}$ & $65.51 \pm 1.66^{\mathrm{aA}}$ & $70.79 \pm 2.55^{\mathrm{bB}}$ & $70.29 \pm 1.83^{\mathrm{abB}}$ \\
\hline & 3 & $61.99 \pm 8.25^{\mathrm{cdA}}$ & $70.67 \pm 4.25^{\mathrm{cB}}$ & $67.72 \pm 6.63^{\mathrm{aAB}}$ & $68.89 \pm 8.94^{\mathrm{aAB}}$ & $68.56 \pm 7.38^{\mathrm{bAB}}$ & $67.53 \pm 6.09^{\mathrm{aAB}}$ \\
\hline & 6 & $54.22 \pm 10.67^{\mathrm{bcA}}$ & $49.31 \pm 5.48^{\mathrm{aA}}$ & $72.37 \pm 2.52^{\mathrm{aB}}$ & $71.20 \pm 8.39^{\mathrm{aB}}$ & $64.49 \pm 6.28^{\mathrm{bB}}$ & $65.04 \pm 8.50^{\mathrm{aB}}$ \\
\hline & 9 & $45.46 \pm 7.27^{\mathrm{aA}}$ & $56.31 \pm 8.42^{\mathrm{bB}}$ & $69.14 \pm 7.23^{\mathrm{bC}}$ & $78.18 \pm 2.54^{\mathrm{bD}}$ & $57.73 \pm 7.26^{\mathrm{cB}}$ & $69.42 \pm 3.02^{\mathrm{abD}}$ \\
\hline & 12 & $46.93 \pm 7.22^{\mathrm{ab**} 6)}$ & -7) & - & - & - & $56.16 \pm 8.01^{\mathrm{bc} * *}$ \\
\hline \multirow{5}{*}{$a^{*}$} & 0 & $-16.68 \pm 3.32^{\mathrm{aA}}$ & $-16.61 \pm 2.31^{\mathrm{aA}}$ & $-12.75 \pm 2.19^{\mathrm{aBC}}$ & $-14.32 \pm 1.67^{\mathrm{aAB}}$ & $-10.81 \pm 2.33^{\mathrm{aC}}$ & $-14.14 \pm 0.73^{\mathrm{aB}}$ \\
\hline & 3 & $0.59 \pm 2.28^{\mathrm{bC}}$ & $-9.75 \pm 2.91^{\mathrm{bA}}$ & $-7.08 \pm 4.35^{\mathrm{bAB}}$ & $-5.29 \pm 0.90^{\mathrm{bB}}$ & $-0.53 \pm 3.67^{\mathrm{bC}}$ & $-6.78 \pm 2.02^{\mathrm{cAB}}$ \\
\hline & 6 & $4.53 \pm 2.11^{\mathrm{cE}}$ & $5.91 \pm 1.75^{\mathrm{cE}}$ & $-5.72 \pm 2.50^{\mathrm{bB}}$ & $-2.18 \pm 0.76^{\mathrm{cC}}$ & $2.28 \pm 2.41^{\mathrm{cD}}$ & $-8.81 \pm 2.61^{\mathrm{bA}}$ \\
\hline & 9 & $8.07 \pm 0.75^{\mathrm{dD}}$ & $4.53 \pm 2.04^{\mathrm{cC}}$ & $3.96 \pm 2.28^{\mathrm{cC}}$ & $0.22 \pm 1.11^{\mathrm{dB}}$ & $7.30 \pm 0.99^{\mathrm{dD}}$ & $-1.97 \pm 1.73^{\mathrm{dA}}$ \\
\hline & 12 & $8.30 \pm 1.64^{\mathrm{d}^{*}}$ & - & - & - & - & $1.49 \pm 1.94^{\mathrm{e}^{*}}$ \\
\hline \multirow{5}{*}{$b^{*}$} & 0 & $43.02 \pm 1.80^{\mathrm{bA}}$ & $45.09 \pm 2.17^{\mathrm{bAB}}$ & $45.80 \pm 1.77^{\mathrm{abBC}}$ & $44.43 \pm 1.30^{\mathrm{aABC}}$ & $46.15 \pm 3.30^{\mathrm{aBC}}$ & $46.44 \pm 1.05^{\mathrm{aC}}$ \\
\hline & 3 & $38.85 \pm 8.14^{\mathrm{bA}}$ & $49.36 \pm 3.41^{\mathrm{bB}}$ & $46.41 \pm 7.59^{\mathrm{abB}}$ & $44.85 \pm 2.73^{\mathrm{aAB}}$ & $46.94 \pm 6.45^{\mathrm{bB}}$ & $45.04 \pm 4.84^{\mathrm{aAB}}$ \\
\hline & 6 & $42.14 \pm 4.99^{\mathrm{bB}}$ & $27.32 \pm 5.20^{\mathrm{aA}}$ & $49.97 \pm 5.40^{\mathrm{bCD}}$ & $51.88 \pm 4.25^{\mathrm{bD}}$ & $43.00 \pm 5.69^{\mathrm{bB}}$ & $45.43 \pm 5.79^{\mathrm{aBC}}$ \\
\hline & 9 & $24.26 \pm 7.58^{\mathrm{aA}}$ & $32.98 \pm 9.82^{\mathrm{aB}}$ & $40.34 \pm 9.33^{\mathrm{aB}}$ & $51.54 \pm 5.02^{\mathrm{bC}}$ & $36.51 \pm 8.18^{\mathrm{bB}}$ & $56.23 \pm 7.38^{\mathrm{bC}}$ \\
\hline & 12 & $26.30 \pm 6.66^{\mathrm{a}^{* *}}$ & - & - & - & - & $56.54 \pm 8.69^{b^{* *}}$ \\
\hline \multirow{5}{*}{$\Delta \mathrm{E}$} & 0 & $0.00 \pm 0.00^{\mathrm{aA}}$ & $0.00 \pm 0.00^{\mathrm{aA}}$ & $0.00 \pm 0.00^{\mathrm{aA}}$ & $0.00 \pm 0.00^{\mathrm{aA}}$ & $0.00 \pm 0.00^{\mathrm{aA}}$ & $0.00 \pm 0.00^{\mathrm{aA}}$ \\
\hline & 3 & $22.06 \pm 6.00^{\mathrm{bB}}$ & $11.41 \pm 5.85^{\mathrm{bA}}$ & $10.34 \pm 8.20^{\mathrm{bA}}$ & $12.85 \pm 2.80^{\mathrm{bA}}$ & $15.42 \pm 4.33^{\mathrm{bA}}$ & $10.49 \pm 4.90^{\mathrm{bA}}$ \\
\hline & 6 & $26.95 \pm 6.92^{\mathrm{bD}}$ & $33.91 \pm 7.03^{\mathrm{dE}}$ & $10.37 \pm 3.29^{\mathrm{bA}}$ & $18.11 \pm 4.23^{\mathrm{cC}}$ & $16.07 \pm 5.60^{\mathrm{bBC}}$ & $12.63 \pm 3.71^{\mathrm{bAB}}$ \\
\hline & 9 & $36.07 \pm 6.96^{\mathrm{bC}}$ & $29.60 \pm 7.98^{\mathrm{cB}}$ & $20.61 \pm 7.42^{\mathrm{cA}}$ & $21.42 \pm 1.92^{\mathrm{bcA}}$ & $25.72 \pm 7.64^{\mathrm{bAB}}$ & $19.37 \pm 5.00^{\mathrm{cA}}$ \\
\hline & 12 & $37.67 \pm 6.49^{\mathrm{c}^{* * *}}$ & - & - & - & - & $23.47 \pm 2.08^{\mathrm{d}^{* *}}$ \\
\hline
\end{tabular}

${ }^{1)} \mathrm{L}^{*}$, lightness; $\mathrm{a}^{*}$, redness; $\mathrm{b}^{*}$, yellowness; $\Delta \mathrm{E}$, color different.

${ }^{2)} \mathrm{CON}$, no treatment; CM, applied only $1.5 \%$ carboxymethyl cellulose and $2.0 \%$ Tween 80 ; CM-G, applied CM $+1.5 \%$ green tea extract; CM-R, applied $\mathrm{CM}+1.5 \%$ Rhus chinensis extract; CM-B, applied CM + rice bran extract; CM-M, applied CM + $1.5 \%$ Morus alba extract.

${ }^{3)}$ Values are mean $\pm \mathrm{SD}$ of triplicate determinations.

${ }^{4)}$ Different small letters mean in a between groups of samples by different superscripts are significantly different $(\mathrm{p}<0.05)$ by Duncan's multiple range test.

${ }^{5)}$ Different capital letters mean in a between groups of storage period by different superscripts are significantly different $(\mathrm{p}<0.05)$ by Duncan's multiple range test.

${ }^{6 *^{* * * *}}$ Means in a between groups of sample on 12 days are significantly different $\left({ }^{*} \mathrm{p}<0.05,{ }^{* *} \mathrm{p}<0.01\right)$ by t-test.

${ }^{7}$ Samples were determined to be unsuitable for use in the experiment and were excluded from the experiment.

간 동안 꾸준히 낮은 값을 보였다. 또한 $\mathrm{CM}-\mathrm{M}$ 의 경우, $\mathrm{BI}$ 값이 저장 12 일차까지 $0.458 \pm 0.010$ 으로 유지되었다. 이는 갈 변억제제를 이용하면 과일 표면의 산화적 효소 활성을 낮출 수 있다는 Saba과 Sogvar(2016)의 연구 결과와 같이 상백피 추출물이 포함된 가식성 코팅제를 통해 바나나의 갈색소 함 량을 낮출 수 있었을 것이라고 여겨진다. 키토산과 calcium propionate 복합 코팅처리를 통해 바나나의 갈변 정도를 늦췄 다는 Mirshekari 등(2017)의 연구에서도 유사한 결과를 확인 할 수 있었다. 따라서 CM-M 처리를 통해 갈변을 늦출 수 있
으며, 저장 기간 동안 바나나의 적색도(b* value)를 측정한 결 과와도 데이터 간의 상관관계를 확인할 수 있다.

\section{총 엽록소 함량}

엽록소는 식물의 엽록체 내부에 있는 성분으로 광합성을 위해 빛 에너지를 흡수하는 색소이다(Canjura 등, 1991). 엽 록소가 산화되면 갈색을 띄는 성분으로 변색되고 외관 품질 을 떨어뜨리기 때문에, 총 엽록소 함량은 과일의 신선도를 평 가할 수 있는 지표로 사용될 수 있다(Lee 등, 2001). 가식성 

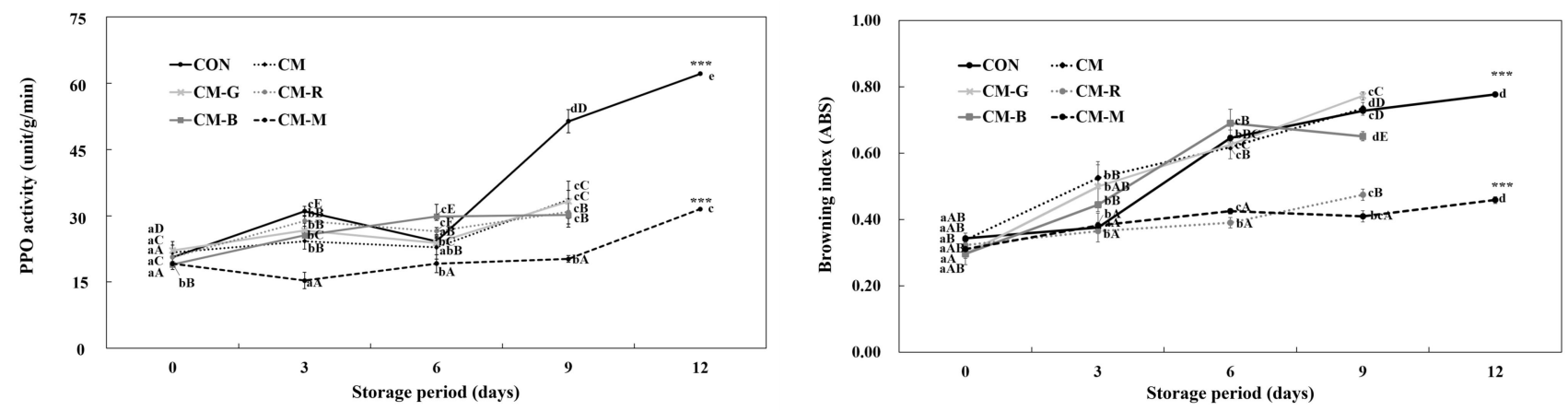

Fig. 4. PPO activity and Browning index of edible coating bananas during storage.

$\mathrm{CON}$, no treatment; CM, applied only $1.5 \%$ carboxymethyl cellulose and 2.0\% Tween80; CM-G, applied CM $+1.5 \%$ green tea extract; CM-R, applied CM $+1.5 \%$ Rhus chinensis extract; CM-B, applied CM + rice bran extract; CM-M, applied CM + $1.5 \%$ Morus alba extract.

Different capital letters mean in a between groups of storage period by different superscripts are significantly different $(p<0.05)$ by Duncan's multiple range test.

Different small letters mean in a between groups of samples by different superscripts are significantly different $(p<0.05)$ by Duncan's multiple range test.

${ }^{* *}$ Means in a between groups of sample on 12 days are significantly different $(\mathrm{p}<0.001)$ by $\mathrm{t}$-test.

코팅 처리한 바나나의 저장 중 총 엽록소 함량의 변화는 Fig. 5 와 같다. 총 엽록소 함량은 모든 샘플에서 저장 3 일차부터 급격하게 감소하는 경향을 보였으며, 특히 $\mathrm{CON}$ 의 경우 저장 6일차부터는 $0.017 \pm 0.004-0.050 \pm 0.004 \mathrm{mg} / \mathrm{g}$ 범위로 유의적 인 차이가 없었으며 매우 낮은 수준을 유지했다. 반면, CM-M 의 경우 저장 12 일차까지 총 엽록소 함량이 $0.047 \pm 0.006$ $\mathrm{mg} / \mathrm{g}$ 수준을 유지하였으며, 총 엽록소 함량의 감소가 느리게 진행되었다. 과일은 수확 후 증산과 호흡 작용과 함께 다양한 효소 작용이 일어나며, 그 결과 색소 성분이 파괴, 지질의 산

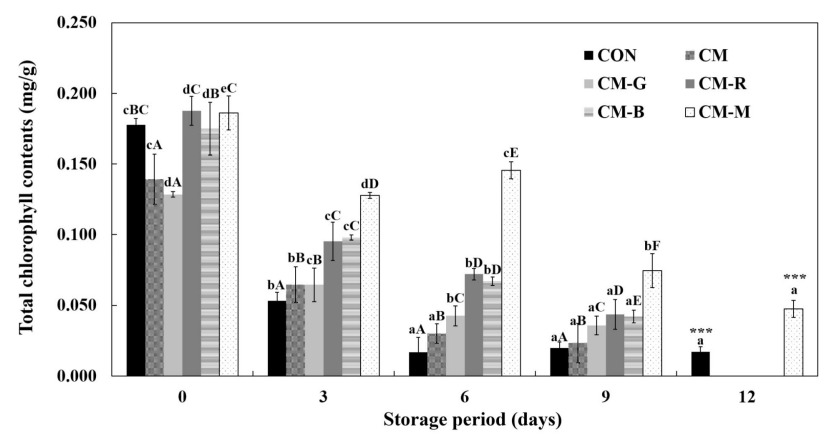

Fig. 5. Total chlorophyll contents of edible coating bananas during storage.

$\mathrm{CON}$, no treatment; $\mathrm{CM}$, applied only $1.5 \%$ carboxymethyl cellulose and $2.0 \%$ Tween 80 ; CM-G, applied CM $+1.5 \%$ green tea extract; CM-R, applied $\mathrm{CM}+1.5 \%$ Rhus chinensis extract; $\mathrm{CM}-\mathrm{B}$, applied $\mathrm{CM}+$ rice bran extract; CM-M, applied CM $+1.5 \%$ Morus alba extract.

Different capital letters mean in a between groups of storage period by different superscripts are significantly different $(p<0.05)$ by Duncan's multiple range test.

Different small letters mean in a between groups of samples by different superscripts are significantly different $(\mathrm{p}<0.05)$ by Duncan's multiple range test.

${ }^{* *}$ Means in a between groups of sample on 12 days are significantly different $(\mathrm{p}<0.001)$ by t-test.
화, 지용성 색소인 엽록소 성분 분해 등이 촉진하게 된다 (Lopez-Ayerra 등, 1998). CM-M의 총 엽록소 함량 변화는 갈변 저해제로 작용하는 상백피 추출물 처리를 통해 항산화 제로서의 작용을 하여 색소 성분의 파괴와 지질의 산화를 늦 췄을 것이라고 사료된다. 또한 과일에 항산화제 처리를 통해 엽록소의 분해를 촉진시키는 역할을 하는 산소를 소거하고, 색소 성분이 분해되는 것을 억제시킨다는 Lee 등(2001)의 연 구 결과를 바탕으로, $\mathrm{CM}-\mathrm{M}$ 처리구가 이와 유사한 현상을 보 이는 것을 확인할 수 있었다. 결론적으로 CM-M 처리를 통해 바나나의 총 엽록소 함량 변화를 가장 낮출 수 있었다고 판단 된다.

\section{색도 및 색차}

바나나 외관의 색상은 숙성에 따른 바나나의 품질 상태 를 판별할 수 있는 중요한 요소 중 하나이다(Mendoza과 Aguilera, 2004). 가식성 코팅 처리한 바나나의 저장 중 총 색도 $\left(\mathrm{CIE} \mathrm{L}{ }^{*} \mathrm{a}^{*} \mathrm{~b}^{*}\right)$ 와 색차 $(\Delta \mathrm{E})$ 의 변화는 Table 1 과 같다. 색도 값의 경우, 전반적으로 저장 기간에 따라 명도 $\left(\mathrm{L}^{*}\right.$ value $)$ 값은 감소하고, 적색도(b" value) 값은 증가하는 경향을 보였으며, 저장 일차 간 유의적 차이를 확인할 수 있었다. 특히 CM-M 의 적색도 값의 경우, 저장 9 일차까지 음의 값을 유지하고, 황색도 값의 경우에도 다른 샘플에 비해 높게 나타나는 것을 통해, 저장 후기까지 바나나의 외관 색상이 녹색에서 밝은 황 색으로 유지되었을 것으로 사료된다. 색차 $(\Delta \mathrm{E})$ 또한 저장 12 일차에서 $\mathrm{CM}-\mathrm{M}$ 의 경우 값이 $23.47 \pm 2.08$ 인 반면 $\mathrm{CON}$ 의 값 은 $37.67 \pm 6.49$ 로 나타나는 것을 보아 가식성 코팅처리를 통 해 저장 기간에 따른 바나나의 외관 색을 오래 유지시킬 수 있었던 것을 확인할 수 있다. 바나나 껍질 색은 숙성 중 녹색 
에서 노란색으로 변하고, 숙성 말기에는 갈색 반점이 발생하 게 되어 결국 전체를 덮게 되는 색 변화 양상을 보이게 되며, 이러한 변화는 효소적 갈변 중 갈색 색소의 합성으로부터 기 인한다(Gomes 등, 2013). 바나나의 숙성에 따른 갈변 현상에 의해 색차에 영향을 줄 수 있고 CM-M을 처리할 경우 바나나 의 효소적 갈변을 방지하여, 저장 후기에서의 값이 $\mathrm{CON}$ 에 비해 낮은 것을 확인할 수 있었다. 상백피의 경우, 효소적 갈 변 반응 저해제로 알려진 tyrosinase의 강한 저해 활성을 나 타낸다는 Choi 등(2015)의 연구 결과를 통해 이를 설명할 수 있다.

\section{요 약}

본 연구는 외관 갈변으로 인해 짧은 유통기한을 가지는 바 나나의 저장성을 증가시키기 위해 다양한 천연 갈변 저해제 (녹차, 붉나무, 쌀겨, 상백피 추출물)를 첨가한 가식성 코팅제 를 제조 후 바나나에 적용하여 저장 중 품질 특성을 분석하였 다. 가식성 코팅처리는 수분 증산과 숙성을 지연시켜 저장 기 간 동안 바나나의 중량 감소율과 경도 변화를 낮췄으며, 특히 코팅제 $(1.5 \% \mathrm{CMC}$ 와 $2.0 \%$ Tween 80$)(\mathrm{CM})$ 에 상백피 추출물 을 첨가한 $\mathrm{CM}-\mathrm{M}$ 처리구에서 변화가 가장 작았다. 또한 $\mathrm{CM}-\mathrm{M}$ 처리는 저장 기간 동안 바나나의 효소적 갈변을 지연 시켜 PPO 활성과 BI 값을 가장 낮게 유지시켰다. 가식성 코 팅 처리를 통해 지용성 색소 성분의 파괴 및 갈색소의 합성을 막아, 총 엽록소 함량과 색도 결과에 있어도 CM-M 값의 변 화가 유의적으로 가장 낮게 나타났다. 따라서 바나나의 품질 특성과 외관을 유지시키는 가식성 코팅제로 녹차, 붉나무, 쌀 겨, 상백피 분말 중에서 상백피 분말을 첨가한 코팅제가 가장 적합하다고 사료되며, 가식성 코팅은 바나나의 저장성을 증 가시킬 수 있는 새로운 포장 방법으로 이용될 수 있을 것으로 판단된다.

\section{Confilict of intereste}

The authors declare no potential conflict of interest.

\section{ORCID}

Jiyoon Kim http://orcid.org/0000-0002-7995-360X

Kwang-Deog Moon http://orcid.org/0000-0001-5277-3345

\section{References}

Adeyemi OS, Oladiji AT. Compositional changes in banana
(Musa ssp.) fruits during ripening. Afr J Biotechnol, 8, 858-859 (2009)

Baldwin EA, Nisperos-Carriedo MO, Baker RA. Use of edible coatings to preserve quality of lightly (and slightly) processed products. Crit Rev Food Sci Nutr, 35, 509-524 (1995)

Canjura FL, Schwartz SJ, Nunes RV. Degradation kinetics of chlorophylls and chlorophyllides. J Food Sci, 56, 1639-1643 (1991)

Cha HS, Youn AR, Kim SH, Jeong JW, Kim BS. Quality analysis of welsh onion (Allium fistulosum L.) as influenced by storage temperature and harvesting period. Korean J Food Sci Tecnol, 40, 1-7 (2008)

Chang MS, Park MJ, Jeong MC, Kim DM, Kim GH. Antioxidative activities and antibrowning effects of green tea extracts and propolis. Korean J Food Cookery Sci, 28, 319-326 (2012)

Chauhan OP, Raju PS, Dasgupta DK, Bawa AS. Instrumental textural changes in banana (Var. Pachbale) during ripening under active and passive modified atmosphere. Int J Food Prop, 9, 237-253 (2006)

Chiumarelli M, Hubinger MD. Stability, solubility, mechanical and barrier properties of cassava starch-carnauba wax edible coatings to preserve fresh-cut apples. Food Hydrocolloids, 28, 59-67 (2012)

Choehom R, Ketsa S, van Doorn WG. Senescent spotting of banana peel is inhibited by modified atmosphere packaging. Postharvest Biol Technol, 31, 167-175 (2004)

Cho JS, Lee HJ, Park JH, Sung JH, Choi JY, Moon KD. Image analysis to evaluate the browning degree of banana (Musa spp.) peel. Food Chem, 194, 1028-1033 (2016)

Choi SW, Lee YJ, Ha SB, Jeon YH, Lee DH. Evaluation of biological activity and analysis of functional constituents from different parts of mulberry (Morus alba L.) tree. J Korean Soc Food Sci Nutr, 44, 823-831 (2015)

Dadzie K, Orchard JE. Routine Post-Harvest Screening of Banana/Plantain Hybrids: Criteria and Methods. Vol. 2. INIBAP Technical Guidelines, International Plant Genetic Resources Institute, Rome, p 75 (1997)

Debeaufort F, Quezada-Gallo JA, Voilley A. Edible films and coatings: Tomorrow's packagings: A review. Crit Rev Food Sci Nutr, 38, 299-313 (1998)

Fernandez-Pan I, Carrion-Granda X, Mate JI. Antimicrobial 
efficiency of edible coatings on the preservation of chicken breast fillets. Food Control, 36, 69-75 (2014)

Ghasemnezhad M, Zareh S, Rassa M, Sajedi RH. Effect of chitosan coating on maintenance of aril quality, microbial population and PPO activity of pomegranate (Punica granatum L. cv. Tarom) at cold storage temperature. J Sci Food Agric, 93, 368-374 (2012)

Gomes JFS, Vieira RR, Leta FR. Colorimetric indicator for classification of bananas during ripening. Sci Hortic, 150, 201-205 (2013)

Hassan B, Chatha SAS, Hussain AI, Zia KM, Akhtar N. Recent advances on polysaccharides, lipids and protein based edible films and coatings: A review. Int $\mathrm{J}$ Biol Macromol, 109, 1095-1107 (2018)

Huang H, Zhu Q, Zhang Z, Yang B, Duan X, Jiang Y. Effect of oxalic acid on antibrowning of banana (Musa spp., AAA group, cv. 'Brazil') fruit during storage. Sci Hortic, 160, 208-212 (2013)

Hur SS. Applying edible coating materials for extending storage life of peeled-garlic. J Korean Oil Chemists Soc, 32, 377-385 (2015)

Eum HL, Hwang DK, Linke M, Lee SK, Zude M. Influence of edible coating on quality of plum (Prunus salicina Lindl. cv. 'Sapphire'). Eur Food Res Technol, 229, 427-434 (2009)

Jang JH, Moon KD. Inhibition of polyphenol oxidase and peroxidase activities on fresh-cut apple by simultaneous treatment of ultrasound and ascorbic acid. Food Chem, 124, 444-449 (2011)

Jatoi MA, Juric S, Vidrih R, Vincekovic M, Vukovic M, Jemric T. The effects of postharvest application of lecithin to improve storage potential and quality of fresh goji (Lycium barbarum L.) berries. Food Chem, 230, 241-249 (2017)

Jee SO. Antioxidant activities and whitening effect of the mulberry (Morus alba L.) root bark extracts. Korean J Plant Res, 22, 145-151 (2009)

Kader AA. Postharvest Technology of Horticultural Crops. 3rd ed, ANR Publication, University of California, USA, p 535 (2002)

Kanatt SR, Makwana SH. Development of active, waterresistant carboxymethyl cellulose-poly vinyl alcoholAloe vera packaging film. Carbohydr Polym, 227, 115303 (2020)
Kim JM, Baek JM, Kim HS, Choe M. Antioxidative and anti-asthma effect of morus bark water extracts. J Korean Soc Food Sci Nutr, 39, $1263-1269$ (2010)

Kim JS, Park JW, Park SH, Choi DS, Kim YH, Lee SJ, Park CW, Lee JS, Cho BK. Effects of modified atmosphere packaging (MAP) and vaporized ethyl pyruvate (EP) treatment for the shelf life of Seolhyang strawberries. Korean J Food Preserv, 24 351-360 (2017)

Kim JW, Youn KS. Effects of ripeness degree on the physicochemical properties and antioxidative activity of banana. Korean J Food Preserv, 20, 475-481 (2013)

Lara-Espinoza C, Carvajal-Millan E, Balandran-Quintana R, Lopez-Franco Y, Rascon-Chu A. Pectin and pectin-based composite materials: Beyond food texture. Molecules, 23, 942 (2018)

Lee SH, Choe EO, Lee HG, Park KH. Factors affecting the components of chlorophyll pigment in spinach during storage. J Korean Soc Appl Biol Chem, 44, 73-80 (2001)

Lopez-Ayerra B, Murcia MA, Garcia-Carmona F. Lipid peroxidation and chlorophyll levels in spinach during refrigerated storage and after industrial processing. Food Chem, 61, 113-118 (1998)

Martinez-Ferrer M, Harper C, Perez-Muntoz F, Chaparro M. Modified atmosphere packaging of minimally processed mango and pineapple fruits. J Food Sci, 67, 3365-3371 (2002)

Mendoza F, Aguilera JM. Application of image analysis for classification of ripening bananas. J Food Sci, 69, 471477 (2004)

Mirshekari A, Madani B, Golding JB. Suitability of combination of calcium propionate and chitosan for preserving minimally processed banana quality. J Sci Food Agric, 97, 3706-3711 (2017)

Noh JS, Park SY, Jeong KS. Extraction characteristics and antioxidant activity of ethanol extract of Rhus javanica Bark. J Oil Applied Science, 34, 555-561 (2017)

Park HJ, Kim GH. Effect of application of rice bran extract on quality of Agaricus bisporus during storage. Korean J Hort Sci Technol, 32, 834-844 (2014)

Rojas-Grau MA, Tapia MS, Martin-Belloso O. Using polysaccharide-based edible coatings to maintain quality of fresh-cut Fuji apples. LWT-Food Sci Technol, 41, 139-147 (2008) 
Saba MK, Sogvar OB. Combination of carboxymethyl cellulose-based coatings with calcium and ascorbic acid impacts in browning and quality of fresh-cut apples. LWT-Food Sci Technol, 66, 165-171 (2016)

Saowakon K, Deewatthanawong R, Khurnpoon L. Effect of carboxymethyl cellulose as edible coating on postharvest quality of rambutan fruit under ambient temperature. Int J Agric Technol, 13, 1449-1457 (2017)

Sheehy T, Sharma S. The nutrition transition in the republic of Ireland: Trends in energy and nutrient supply from 1961 to 2007 using food and agriculture organization food balance sheets. Br J Nutr, 106, 1078-1089 (2011)

Sim HJ, Kang MJ, Shin JH. Changes in the quality characteristics and chemical compounds of garlic shoots for blanching. Korean J Food Preserv, 23, 310-318 (2016)
Son HJ, Kang JH, Oh DH, Min SC, Song KB. Combined treatment of fumaric acid with mild heat to inactivate microorganisms on fresh spinach during storage. J Appl Biol Chem, 59, 69-74 (2016)

Supapvanich S, Pimsaga J, Srisujan P. Physicochemical changes in fresh-cut wax apple (Syzygium samarangenese [Blume] Merrill \& L. M. Perry) during storage. Food Chem, 127, 912-917 (2011)

Tinello F, Lante A. Recent advances in controlling polyphenol oxidase activity of fruit and vegetable products. Innovative Food Sci Emerging Technol, 50, 73-83 (2018)

Yang Z, Zheng Y, Cao S. Effect of high oxygen atmosphere storage on quality, antioxidant enzymes, and DPPH radical scavenging activity of Chinese bayberry fruit. J Agric Food Chem, 57, 176-181 (2009) 